\title{
Enter 9/11: Latin America and the Global War on Terror
}

\author{
Markus-Michael Müller* \\ Assistant Professor of Latin American Politics, Freie Universität Berlin, ZI Lateinamerika-Institut \\ ${ }^{\star}$ Corresponding author. Email: muellerm@zedat.fu-berlin.de.
}

(First published online 4 June 2020)

\begin{abstract}
This article offers an analysis of the transnational discursive construction processes informing Latin American security governance in the aftermath of 9/11. It demonstrates that the Global War on Terror provided an opportunity for external and aligned local knowledge producers in the security establishments throughout the Americas to reframe Latin America's security problems through the promotion of a militarised security epistemology, and derived policies, centred on the region's 'convergent threats'. In tracing the discursive repercussions of this epistemic reframing, the article shows that, by tapping into these discourses, military bureaucracies throughout the Americas were able to overcome their previous institutional marginalisation vis-à-vis civilian agencies. This development contributed to the renaissance of counter-insurgency and counter-terrorism discourses and policies in the region, allowing countries such as Colombia and Brazil to reposition themselves globally by exporting their military expertise for confronting post-9/11 threats beyond the region.
\end{abstract}

Keywords: Global War on Terror; epistemic communities; counter-insurgency; counter-terrorism; Colombia; Brazil

\section{Introduction}

This article addresses the transformation of Latin America's security environment in the aftermath of $9 / 11$ in order to explain the resurgence of counter-terrorism and counter-insurgency-related discourses and policies in the region. It argues that $9 / 11$, together with the global revival of counter-insurgency, from the mid-2000s onwards, provided an opportunity for an 'epistemic community', composed out of external and aligned local actors in the security policy establishments throughout the Americas, to recast the region's security problems. This community facilitated the movement of a Global War on Terror (GWOT)-related security epistemology to Latin America. In turn, by discursively framing the region's contemporary security problems as 'convergent threats' - often understood in terms of a 'crime-terrorinsurgency nexus' - these actors managed to adapt post-9/11 global security epistemologies to Latin American realities. In essence, this reframing allowed for connecting the region's security problems to a GWOT-inspired vocabulary, any medium, provided the original work is properly cited. 
emphasising the terrorist/insurgent qualities of criminal actors in the region while embedding them within a global post-9/11 threat scenario. As a consequence, counter-insurgency and counter-terrorism discourses and policies, which often tend to be associated with Latin America's past, have resurfaced, partly by enabling a reappearance of military discourses and practitioners from the 'Global Cold War' (GCW). ${ }^{1}$ Accordingly, by tapping into these discourses, military bureaucracies throughout the Americas were able to expand their budgets and overcome their previous institutional marginalisation vis-à-vis civilian agencies. This development, moreover, has provided Latin American countries, such as Colombia and Brazil, with an opportunity to reposition themselves globally by (re)branding and exporting their military expertise as a model for confronting 'convergent' post-9/11 security threats beyond the region.

In developing these arguments, the article makes three contributions to the debates on Latin America's 'violent' ${ }^{2}$ and 'securitized' ${ }^{3}$ democracies. First, it assesses the impact of $9 / 11$ on the ways security is governed and violence addressed in the region, topics that have received little attention in contemporary debates. Second, the article explores the transnational dimension of security governance in contemporary Latin America. Although much is known about national and subnational causes and consequences of violence in the region, together with efforts to counter them, ${ }^{4}$ the debate has not yet been upscaled to the level of transnational interactions. Stated otherwise, scholars have largely ignored asking how these local processes are embedded in ongoing reconfigurations of transnational security governance - in particular after 9/11. On the flipside, the possible ways that related Latin American developments have implications beyond the region have been left uncharted. Third, the article unpacks some of the taken-for-granted epistemic underpinnings of the ideas about how to counter violence and govern security in the region, where they come from, who imports them and to what effect. In fact, scholars too often tend to assume the validity of policy vision and practitioners' ideas regarding how to counter violence and govern security. In turn, successes or failures of particular security models are analysed without delving into the knowledge economies that make certain policies travel. ${ }^{5}$

\footnotetext{
${ }^{1}$ Odd Arne Westad, The Global Cold War: Third World Interventions and the Making of Our Times (New York: Cambridge University Press, 2011).

${ }^{2}$ Enrique Desmond Arias and Daniel M. Goldstein (eds.), Violent Democracies in Latin America (Durham, NC: Duke University Press, 2010).

${ }^{3}$ Jenny Pearce, 'Perverse State Formation and Securitized Democracy in Latin America', Democratization, 17: 2 (2010), pp. 286-306.

${ }^{4}$ See, for example, Enrique Desmond Arias, Criminal Enterprises and Governance in Latin America and the Caribbean (Cambridge: Cambridge University Press, 2016); Graham Denyer Willis, The Killing Consensus: Police, Organized Crime, and the Regulation of Life and Death in Urban Brazil (Oakland, CA: University of California Press, 2015); Tina Hilgers and Laura Macdonald (eds.), Violence in Latin America and the Caribbean: Subnational Structures, Institutions, and Clientelistic Networks (Cambridge: Cambridge University Press, 2017); Benjamin Lessing, Making Peace in Drug Wars: Crackdowns and Cartels in Latin America (Cambridge: Cambridge University Press, 2017); Wil Pansters (ed.), Violence, Coercion, and State-Making in Twentieth-Century Mexico (Palo Alto, CA: Stanford University Press, 2012).

${ }^{5}$ But see Paul Hathazy, 'Punitivism with a Human Face: Criminal Justice Reformers' International and Regional Strategies and Penal-State Making in Argentina, Chile and Beyond', Kriminologisches Journal, 48: 4 (2016), pp. 294-310; Louise Wiuff Moe and Markus-Michael Müller, 'Counterinsurgency,
} 
On the following pages, these issues will be explored through an analytical narrative that will assess the epistemological underpinnings of contemporary policy discourses gravitating around 'convergent' security threats in Latin America by assessing how the actors involved discursively 'construct their policy arguments' and to what effect. By drawing upon an analysis of government and policy documents as well as informal and formal military doctrinal publications - and without claiming to offer an exhaustive account of these processes - the narrative will zoom in on key actors and developments that facilitated Latin America's integration into the GWOT. To this end, the narrative will follow the multi-scalar (global, national, regional) travels of the post-9/11 security epistemology and the 'actor-network' that created the underlying conceptual framing of crime-terror-insurgency 'convergences', from the battlefields of the GWOT, to the United States, Latin America and beyond.

\section{Converging Post-9/11 Threats}

The terrorist attacks of 9/11 profoundly transformed the global security environment. Today, there seem to be widespread international concerns regarding the global threat potential of Islamist terrorism, ${ }^{7}$ whose transnational structures, religious inspiration and increased operational lethality seem to indicate a 'new' quality of the contemporary terrorism landscape. ${ }^{8}$

Latin America, however, is rarely perceived as a target of Islamist terrorism. As a recently published report by the US Congressional Research Service argues, ' $[c]$ ompared to other parts of the world, the potential threat emanating from terrorism is low in most countries in Latin America'. The acts of terrorism that are identified in the report predominantly occur in the Andean region of South America, committed by two Colombian guerrilla groups - Fuerzas Armadas Revolucionarias de Colombia (Revolutionary Armed Forces of Colombia, FARC) and Ejército de Liberación Nacional (National Liberation Army, ELN) - and one Peruvian guerrilla group, Sendero Luminoso (Shining Path, SL). ${ }^{9}$ As these insurgent groups are neither Islamist nor new threats to the affected countries, the question arises how and why a region that is not home to, nor significantly targeted by, transnational Islamist terrorism became integrated into the post- $9 / 11$ security context. To answer this query, the role of epistemic communities in the rise of the 'new

Knowledge Production and the Traveling of Coercive Realpolitik between Colombia and Somalia', Cooperation and Conflict, 53: 2 (2018), pp. 193-215.

${ }^{6}$ Frank Fischer, 'Policy Analysis in Critical Perspective: The Epistemics of Discursive Practices', Critical Policy Studies, 1: 1 (2007), p. 103.

${ }^{7}$ See, for example, United Nations Security Council, 7272nd Meeting, 'Threats to International Peace and Security' (New York: UN, 2014); United Nations Office on Drugs and Crime, Foreign Terrorist Fighters: Manual for Judicial Training Institutes, South-Eastern Europe (Vienna: UNODC, 2017); US Department of State, Bureau of Counterterrorism and Countering Violent Extremism, Country Reports on Terrorism (Washington, DC: Department of State, 2017), pp. 9-13.

${ }^{8}$ Peter R. Neumann, Old and New Terrorism: Late Modernity, Globalization and the Transformation of Political Violence (Cambridge: Polity, 2009), pp. 14-48.

${ }^{9}$ Mark P. Sullivan and June S. Beittel, Latin America: Terrorism Issues (Washington, DC: Congressional Research Service, 2016), p. i. 
counterinsurgency era ${ }^{10}$ within the context of the GWOT needs to be assessed. These communities managed to promote a post-9/11 security worldview that discursively connects the issues of insurgency and terrorism by stressing the connections between these phenomena, on the one hand, and relating them to crime, on the other. In making this security epistemology, gravitating around concepts such as the crime-terror-insurgency nexus, ${ }^{11}$ travel to Latin America, these communities adapted its underlying threat scenario and policy prescriptions to the region's realties by reframing criminal actors, such as street gangs, as terrorists and/or insurgents, ${ }^{12}$ as well as placing them in a global post-9/11 context.

\section{Travelling Epistemologies}

As with all other forms of governance, security governance - including threat perceptions as well as related prescripts on how to tackle them - is related to dominant forms of knowing, or epistemologies, which construct political reality and ways of ordering it. This construction is based on making truth claims concerning governance problems and solutions that are grounded in knowledge. ${ }^{13}$

When it comes to particular policies, globally dominant epistemologies reflect the power and influence of what Peter M. Haas termed 'epistemic communities'. These communities are composed of networks of recognised experts who share a 'set of normative and principled beliefs'. Members of epistemic communities usually have a 'competence in a particular domain and an authoritative claim to policyrelevant knowledge within that domain or issue-area'. ${ }^{14}$ They also often share a common educational, institutional and/or professional background and seek to transform a current state of affairs by mobilising their acquired, collectively shared and recognised knowledge. ${ }^{15}$ As epistemic communities operate in a highly competitive economy, their claim to be in the exclusive possession of uniquely relevant knowledge for solving pressing governance problems is crucial for prevailing in such an environment by enabling an epistemic community to credibly uphold the claim of knowing the 'way forward'. Accordingly, an epistemic community's power depends upon the promotion of specific 'success models' and solutions to

\footnotetext{
${ }^{10}$ David Ucko, The New Counterinsurgency Era: Transforming the U.S. Military for Modern Wars (Washington, DC: Georgetown University Press, 2009).

${ }^{11}$ Michael Miklaucic and Jacqueline Brewer, 'Introduction', in Michael Miklaucic and Jacqueline Brewer (eds.), Convergence: Illicit Networks and National Security in the Age of Globalization (Washington, DC: National Defense University Press, 2013), p. xiii. This nexus is also discussed as the 'crime-terror continuum' or the 'crime-terror interface'; see Peter Grabosky and Michael Stohl, Crime and Terrorism (Los Angeles, CA: Sage, 2010), pp. 6-8, 71-86.

${ }^{12}$ Markus-Michael Müller, 'Punitive Entanglements: The "War on Gangs" and the Making of a Transnational Penal Apparatus in the Americas', Geopolitics, 20: 3 (2015), pp. 696-727; Elana Zilberg, Space of Detention: The Making of a Transnational Gang Crisis between Los Angeles and El Salvador (Durham: Duke University Press 2011), pp. 220-7.

${ }^{13}$ Jan-Peter Voß and Richard Freeman (eds.), Knowing Governance: The Epistemic Construction of Political Order (Basingstoke: Palgrave Macmillan, 2016).

${ }^{14}$ Peter M. Haas, 'Introduction: Epistemic Communities and International Policy Coordination', International Organization, 46: 1 (1992), p. 3.

${ }^{15}$ Susana Durão, 'Formação internacional, comunidades de saberes e mudança institucional: os oficiais de polícia africanos formados em Lisboa', Revista Brasileira de Segurança Pública, 9: 1 (2015), pp. 131-2.
} 
address governance problems in a way that derived policy proposals resonate with changing global (geo)political context conditions and related preferences - normative, political and economic - of policy-makers. Other relevant factors include the authority of the knowledge producers themselves, which is related to the power/ influence of the network in which they are embedded as well as the related access to dominant policy actors and institutions, both at home and abroad. ${ }^{16}$

These communities, as Haas argues, 'are channels through which new ideas circulate from societies to governments as well as from country to country' by articulating 'cause-and-effect relationships of complex problems, helping states identify their interests, framing the issues for collective debate, proposing specific policies, and identifying salient points for negotiation'. ${ }^{17}$

Epistemic communities, in this regard, are important for assessing the mobility of policies as well as the multi-scalar institutional and personal networks involved in their construction. ${ }^{18}$ These communities provide for the 'social infrastructure' of globally mobile policies, as Jamie Peck and Nik Theodore have shown, which creates deep interconnections amongst people, institutions and places by enabling a 'cross-referential intensity' in and through which particular policy ideas come to express a commonly shared consensus regarding 'models', 'best practices', new governance technologies and problem framings. ${ }^{19}$ Such shared consensus, before it becomes official policy, however, is established through a more subterranean process in which new epistemologies circulate throughout expert networks, often in informal ways, and regularly through publications. ${ }^{20}$

Publications are indeed the core means for the dissemination of an epistemic community's 'new ideas' and the emergence of a network-wide accepted epistemic vocabulary. The latter usually takes the form of concepts, such as the "crime-terrorinsurgency nexus', which form the 'analytical backbone' of mobile policies. ${ }^{21}$ These concepts render particular contexts legible, make them comparable and allow them to be linked, against the backdrop of analytically pre-established categories through which initially unrelated objects are grouped together 'as instances of the same kind of thing. ${ }^{22}$ Such concepts are brought to life through the collective work of epistemic networks and the associations of the actors involved. As Christian Bueger and Felix Bethke have put it by drawing on insights from Bruno Latour's actornetwork theory: ${ }^{23}$

\footnotetext{
${ }^{16}$ Moe and Müller, 'Counterinsurgency', p. 207.

${ }^{17}$ Haas, 'Introduction', pp. 27, 2.

${ }^{18}$ Tim Newburn, Trevor Jones and Jarrett Blaustein, 'Policy Mobilities and Comparative Penality', Theoretical Criminology, 22: 4 (2018), p. 572.

${ }^{19}$ Jamie Peck and Nik Theodore, Fast Policy: Experimental Statecraft at the Threshold of Neoliberalism (Minneapolis, MN: University of Minnesota Press, 2015), p. xxiv.

${ }^{20}$ Graham Ellison and Nathan W. Pino, Globalization, Police Reform and Development: Doing it the Western Way? (Basingstoke: Palgrave Macmillan, 2012), p. 78.

${ }^{21}$ Peck and Theodore, Fast Policy, p. 67.

${ }^{22}$ Nick Riemer, 'Internalist Semantics. Meaning, Conceptualization and Expression', in Nick Riemer (ed.), The Routledge Handbook of Semantics (Abingdon: Routledge, 2016), p. 32.

${ }^{23}$ Bruno Latour, Reassembling the Social: An Introduction to Actor-Network Theory (Oxford: Oxford University Press, 2005).
} 
Initially, a concept is an effect of a web of associations. A novel concept is an innovation brought about by such a web. Understanding the life of the concept is to investigate the work that goes into weaving this net - to study the actors who conduct this work and are part of the net [...] The materials that make up a network giving life to a concept are mainly texts and actors producing these texts, reading these texts and adjusting their [discursive] behaviour to these texts. $^{24}$

In line with actor-network theory, focusing on the conceptual work of epistemic communities - together with the underlying dynamics of the 'web of associations' that connects people, institutions and places - offers a methodological roadmap for studying these processes from a relational perspective. Latour's proposal 'to follow the actors themselves', which requires trying to 'catch up with their often wild innovations' while recognising 'the multiplicity of agencies ${ }^{25}$ involved in rendering policies mobile, allows institutional, geographic and actor-related 'interconnections' to be uncovered. As Timothy Mitchell puts it, one can 'establish the routes along which facts [and the concepts rendering them legible] can travel and be confirmed' by examining the wider 'political and intellectual arrangements of which they form a part'. ${ }^{26}$

Emphasising such 'interconnections' calls for a focus on local interests that embrace externally provided models and concepts as well as on the wider resonances such models have in specific contexts. Such resonance and appeal usually imply a conceptual reassembling through which local actors cherry-pick the symbolic, material, discursive and/or practical elements of mobile policies that are most relevant for pursuing their own interests. This involves a transformation of the original ideas and models according to local needs. ${ }^{27}$

By concentrating on the role of epistemic communities in the resurgence of counter-insurgency within the context of the GWOT, and by following the actors as well as travelling concepts involved - which have increasingly interwoven the issues of (counter)insurgency, (counter)terrorism and crime - the remainder of this article will demonstrate how and why Latin America 'entered' the global post-9/11 security context.

\section{The New Counter-Insurgency Era}

Around 2005-6, counter-insurgency witnessed a revival within the GWOT, notably within the United States. Faced with continuous setbacks in Iraq and Afghanistan, the US military initiated a practical and doctrinal shift from 'conventional' warfare towards more 'unconventional' counter-insurgency operations. ${ }^{28}$ The growing attention paid to counter-insurgency within the GWOT, which has been portrayed

\footnotetext{
${ }^{24}$ Christian Bueger and Felix Bethke, 'Actor-networking the "Failed State": An Enquiry into the Life of Concepts', Journal of International Relations and Development, 17: 1 (2014), pp. 40-1.

${ }^{25}$ Latour, Reassembling the Social, pp. 12, 260.

${ }^{26}$ Timothy Mitchell, 'The Work of Economics: How a Discipline Makes its World', European Journal of Sociology, 46: 2 (2005), p. 304.

${ }^{27}$ Peck and Theodore, Fast Policy, p. 29.

${ }^{28}$ Ucko, The New Counterinsurgency Era.
} 
as a new 'prototypical form of warfare' marked by 'a mutation or fusion of insurgency and terrorism,, 29 has increasingly bound together counter-insurgency and counter-terrorism to an extent that successfully combatting terrorism also means countering insurgencies, and vice versa.

Debates on terrorism and insurgency, moreover, have increasingly focused on crime. In fact, it became more and more clear that many GWOT insurgents, notably the Taliban in Afghanistan, financed their activities through criminal activities, particularly drug trafficking. As influential policy scholar Vanda Felbab-Brown puts it:

Afghanistan has become one of the most important locations in the U.S. struggle against terrorism, along with Iraq, its main theater of counterinsurgency operations against the resurgent Taliban, which has been deeply involved in the drug trade despite first proscribing it as un-Islamic. Thus, for the United States, Afghanistan has come to epitomize the nexus of drugs and insurgency. ${ }^{30}$

Such reasoning on the 'nexus of drugs and insurgency' was especially well received by US government officials, who, already before $9 / 11$, had started to worry about crimeterrorism 'convergences'. Apparently evidenced by the fact that the financing of terrorist organisations throughout the world, to varying degrees, depends upon drug trafficking, fears about such convergences also enveloped Latin America, particularly Colombia. Here, FARC's ability to control parts of Colombian territory, in addition to its alleged ties to the Russian mafia and Mexican cartels, transformed Colombia's security context. As Michael A. Sheehan, then-coordinator for counter-terrorism at the Department of State (DoS), expressed in 2000, Colombia became 'the primary example of narcoterrorism in the world where the drug trade is a major factor in terrorism activities'. ${ }^{31}$ These worries were exacerbated by $9 / 11$. And at a critical GWOT juncture, publications, such as the ones by Felbab-Brown, made the idea of a nexus between drugs, terrorism and insurgency so popular ${ }^{32}$ that in the wider US foreign policy establishment the crime-terror-insurgency nexus became part and parcel of official policy discourses.

This points towards the influence of an epistemic community within the US security establishment, which Thomas E. Ricks terms 'COINdinistas': a network of people whose epistemological work facilitated the resurgence of counterinsurgency in the US military and foreign policy establishment. ${ }^{33}$ Institutionally and personally connected by a shared professional interest, or what Haas calls a 'common policy enterprise', the actor-network comprising the COINdinistas can be analysed as an epistemic community because the actors involved share 'a set

\footnotetext{
${ }^{29}$ Robert M. Cassidy, Counterinsurgency and the Global War on Terror: Military Culture and Irregular War (Westport, CN: Praeger, 2006), p. 15.

${ }^{30}$ Vanda Felbab-Brown, Shooting Up: Counterinsurgency and the War on Drugs (Washington, DC: Brookings, 2009), p. 9.

${ }^{31}$ 'Threat Posed by the Convergence of Organized Crime, Drug Trafficking and Terrorism. Hearing before the Subcommittee on Crime of the Committee on the Judiciary, House of Representatives, 13 Dec. 2000' (Washington, DC: US Government Printing Office, 2000), pp. 31, 13.

${ }^{32}$ Strobe Talbott, 'Foreword', in Felbab-Brown, Shooting Up, p. ix.

${ }^{33}$ Thomas E. Ricks, 'The COINdinistas', Foreign Policy, 30 Nov. 2009.
} 
of common practices associated with a set of problems to which their professional competence is directed, presumably out of the conviction that human welfare will be enhanced as a consequence. ${ }^{34}$ Enhancing 'human welfare', in this case, means promoting counter-insurgency.

This epistemic community emerged with the post-9/11 revival of the GCW-era US (counter)insurgency industry, a network of people and institutions addressing policy demands for actionable (counter)insurgency knowledge, ${ }^{35}$ now reborn as a 'counterterrorism/counterinsurgency industry'. ${ }^{36}$ In addition to militaries and intelligence services, this industry is composed of government agencies, such as parts of the DoS, or the United States Agency for International Development (USAID), academics, journalists, think tanks, public and private research institutions, such as the Research and Development (RAND) Corporation, the National Defense University (NDU) or the Center for a New American Security (CNAS), as well as private contractors and consultants. ${ }^{37}$ This community, whose main activity is the production and dissemination of insurgency-related knowledge, managed to reframe the problems in Afghanistan and Iraq through the lens of counter-insurgency and provide derived policy recommendations regarding the 'way forward'. Its most influential members, as identified by Ricks, ${ }^{38}$ include: General (ret.) David Petraeus, former commander of the International Security Assistance Force in Afghanistan and commanding general of the Multi-National Force - Iraq; Lieutenant Colonel (ret.) John A. Nagl, former CNAS vice-president; David Kilcullen, a former Australian soldier and advisor to the DoS as the chief strategist in the Office of the Coordinator for Counterterrorism and one of the world's leading counter-insurgency theoreticians; ${ }^{39}$ Janine Davidson, at that time director of stability operations capabilities within the Office for Special Operations/Low Intensity Conflict of the US Assistant Secretary of Defense, as well as founding director of the Consortium for Complex Operations, which later became the NDU-based Center for Complex Operations; ${ }^{40}$ and Dave Dilegge, founder and co-editor-in-chief of the Small Wars Journal (SWJ), which by that time 'became a must read for people in uniform who were looking for answers to the problems they faced in Iraq and Afghanistan'. ${ }^{41}$

In 2006, the epistemic work of the COINdinistas culminated in the publication of the US Army/Marine Corps Counterinsurgency Field Manual FM 3-24 (hereafter

\footnotetext{
${ }^{34}$ Haas, 'Introduction', p. 3.

${ }^{35}$ Steven Metz, 'Rethinking Insurgency', in Paul B. Rich and Isabelle Duyvesteyn (eds.), The Routledge Handbook of Insurgency and Counterinsurgency (Abingdon: Routledge, 2012), p. 32, fn. 1.

${ }^{36}$ Jeremy Scahill, Dirty Wars: The World is a Battlefield (New York: Nation, 2013), p. 468.

${ }^{37}$ Nathan Hodge, Armed Humanitarians: The Rise of the Nation Builders (New York: Bloomsbury, 2011), pp. 10-16, 181-2, 268; Fred Kaplan, The Insurgents: David Petraeus and the Plot to Change the American Way of War (New York: Simon and Schuster, 2013), pp. 98, 140-1.

${ }^{38}$ Ricks, 'The COINdinistas'.

${ }^{39}$ Key publications include David Kilcullen, The Accidental Guerrilla: Fighting Small Wars in the Midst of a Big One (Oxford: Oxford University Press, 2009); Counterinsurgency (Oxford: Oxford University Press, 2010); Coming Out of the Mountains: The Coming Age of the Urban Guerrilla (Oxford: Oxford University, 2013).

${ }^{40}$ See http://smallwarsjournal.com/blog/cco-update-new-home-for-the-consortium-for-complex-operations, last access 15 Jan. 2020.

${ }^{41}$ Hodge, Armed Humanitarians, p. 150.
} 
$F M$ 3-24), ${ }^{42}$ which moved counter-insurgency from an 'enemy-centric' towards a 'population-centric' focus. Instead of just killing adversaries, this meant stressing ' $\mathrm{t}$ ] he importance of protecting the populace, gaining people's support by assisting them, and using measured force when fighting insurgents'. ${ }^{43}$ Rebranding counterinsurgency as 'population-centric' included conceptual work that - partly by drawing on Max Weber's understanding of political authority and Robert D. Putnam's concept of 'social capital ${ }^{\text {'4 }}$ - turned the 'protecting the people' mantra into military doctrine by reconceptualising counter-insurgency as a form of 'armed social work', seeking 'to redress basic social and political problems while being shot at'. ${ }^{45}$ Part of the social and political problem that needed addressing was crime, in particular drug trafficking. As FM 3-24 puts it: 'Sustainment requirements often drive insurgents into relationships with organized crime or into criminal activity themselves. Reaping windfall profits and avoiding the costs and difficulties involved in securing external support makes illegal activity attractive to insurgents. [...] Drugs retain the highest potential for obtaining large profits from relatively small investments. ${ }^{46}$

In many ways, this perspective revived late GCW framings regarding the connections between drug trafficking, terrorism and insurgencies. Exemplified by National Security Division Directive (NSDD) 221, signed by President Ronald Reagan in April 1986, such framings articulated national security concerns regarding 'nations with a flourishing narcotics industry, where a combination of international criminal trafficking organizations, rural insurgents, and urban terrorists can undermine the stability of the local government'. ${ }^{47}$

Back then, such reasoning reflected the conservative zeitgeist, as, for many US citizens, drug trafficking was the main international concern. ${ }^{48}$ In turn, supporters of the militarisation of the drug war could claim both a moral high ground and popular legitimacy. Following the issuing of NSDD 221, security bureaucracies including those working on Latin America, and specifically the US Department of Defense (DoD), which in 1988 became 'the single lead agency for the detection and monitoring of aerial and maritime transit of illegal drugs into the United States $^{\prime 49}$ - benefitted from this militarised reframing of 'interconnected' drug trafficking through enhanced budgets, new forms of interagency cooperation and the provision of new 'opportunities to test equipment, personnel and tactics'. ${ }^{50}$

The end of the GCW marked a shift from such militarisation efforts and underlying geopolitical agendas towards a more civilian-led law enforcement approach to

\footnotetext{
${ }^{42}$ See Kaplan, The Insurgents.

${ }^{43} F M$ 3-24, 5-65. (Please note that military doctrinal publications, usually, have no page numbers. Throughout this article, the numbers/letters noted after such publications refer to paragraphs/subsections.)

${ }^{44}$ Ibid., 3-61, 3-63.

${ }^{45}$ Ibid., A-45.

${ }^{46} \mathrm{Ibid}$., I-56.

${ }^{47}$ NSDD 221: Narcotics and National Security' (Washington, DC: The White House, 1986), p. 2, available at www.cia.gov/library/readingroom/docs/CIA-RDP90B01390R000100120029-5.pdf, last access 28 Feb. 2020.

${ }^{48}$ Ted Galen Carpenter, Bad Neighbor Policy: Washington's Futile War on Drugs in Latin America (New York: Palgrave Macmillan, 2003), p. 32.

${ }^{49}$ US Congressional Record. 'Proceedings and Debates of the $100^{\text {th }}$ Congress, Second Session, Vol. 134, Pt. 18' (Washington, DC: Government Printing Office, 1988), p. 26331.

${ }^{50}$ Carpenter, Bad Neighbor Policy, p. 32.
} 
drug trafficking. This partly reflected civilian security agencies' ability to capitalise on GCW framings of drug trafficking as a national security threat in their search for new post-Cold War security missions, allowing them to enhance their international presence in places now 'vacated' by the military. ${ }^{51}$ In turn, related security budgets focused on law enforcement efforts that prioritised interagency cooperation between the Department of Justice, the DoS and the Department of Treasury, thereby somewhat marginalising the DoD and its late-Cold War approach to drug trafficking - globally and in Latin America. ${ }^{52}$

Accordingly, from the early to mid-1990s onwards, and in line with a broader US effort for democracy promotion in the region, counter-narcotics security assistance increasingly focused on civil police forces, rule of law promotion and law enforcement efforts, ${ }^{53}$ with most of the direct US involvement being coordinated by the DoS' Bureau of International Narcotics and Law Enforcement Affairs. As a derived effect, the US Southern Command (SOUTHCOM), responsible for Latin America - with the exception of Mexico - was turned into the weakest of the US unified combatant commands. After the GCW, the war on drugs was literally the only war left to fight in the western hemisphere, and SOUTHCOM was forced to take on a more indirect, supportive role vis-à-vis its civilian counterparts now conducting most operations on the ground in the region. ${ }^{54}$

This development was reversed by $9 / 11$. It triggered a significant shift of resources from the DoS to the DoD, giving the latter a key role in shaping US foreign policy by framing it in GWOT terms. For Latin America, this implied a strengthening of SOUTHCOM as a key agenda-setter. By jumping on Washington's counter-terrorism agenda, SOUTHCOM has been able to secure and legitimise an expanded budget. ${ }^{55}$ In turn, this triggered a wider shift in perspectives on hemispheric security issues, contributing to the fact 'policymakers elsewhere in the U.S. government have begun to approach Latin America from a disproportionately security threat-based point of view'. ${ }^{56}$ The rediscovery of the drug trafficking-terrorism-insurgency linkages in the region was part and parcel of this development. And, by adapting GWOT-related security epistemologies to Latin American realities, a Latin America-focused subgroup of the abovementioned epistemic community was a key driving force behind this development.

\footnotetext{
${ }^{51}$ Ethan Nadelmann, Cops across Borders: The Internationalization of U.S. Criminal Law Enforcement (University Park, PA: Pennsylvania State University Press, 1993), p. 473.

${ }^{52}$ Peter Andreas and Ethan Nadelmann, Policing the Globe: Criminalization and Crime Control in International Relations (Oxford: Oxford University Press, 2006), pp. 169-74.

${ }^{53}$ Stephen Johnson, Johanna Mendelson Forman and Katherine Bliss, Police Reform in Latin America: Implications for US Policy (Washington, DC: Center for Strategic Studies and International Affairs, 2012), pp. 16-17. See also Rachel Neild, 'U.S. Police Assistance and Drug Control Policies', in Coletta A. Youngers and Eileen Rosin (eds.), Drugs and Democracy in Latin America: The Impact of U.S. Policy (Boulder: CO: Lynne Rienner, 2005), pp. 61-97.

${ }^{54}$ Adam Isacson, 'The U.S. Military and the War on Drugs', in Youngers and Rosin (eds.), Drugs and Democracy, pp. 28-32.

${ }^{55} \mathrm{See} \quad$ www.coha.org/us-southern-command-southcom-struggles-to-justify-its-role-in-the-war-on-terror/, last access 15 Jan. 2020; Jeffrey M. Michaels, The Discursive Trap and the US Military: From the War on Terror to the Surge (Basingstoke: Palgrave Macmillan, 2013), pp. 69-72.

${ }^{56} \mathrm{R}$. Guy Emerson, 'Radical Neglect? "The War on Terror" and Latin America', Latin American Politics and Society, 52: 1 (2010), p. 40.
} 


\section{Constructing Latin America's Criminal Insurgencies}

From the mid-2000s onwards, this subgroup - with close links to many of the previously mentioned outlets of the post-9/11 'counter-terrorism/counter-insurgency industry', and often with direct work experiences regarding Latin American security issues (the actor-network includes former GCW warriors, security consultants, US law enforcement personnel and scholars working on the region, often at military research institutions) - discursively reconfigured policy framings of the region's crime problems that fuelled the above-mentioned 'threat-based' policy view on Latin America. Key to this was conceptual work that culminated in the invention of a generic insurgency concept, that of 'criminal insurgencies', with the community connecting this reframing to post-9/11 US homeland security discourses and the GWOT. In doing so, this actor-network discursively expanded counterinsurgency and counter-terrorism logics into the realm of law enforcement while subjugating the latter to military prerogatives in order to confront the region's 'criminal insurgents' and 'convergent threats'. By drawing practical similarities between 'classic' and 'criminal' insurgents, the latter, in turn, have been elevated above the realm of ordinary 'local' criminality and instead portrayed as part of a global post-9/11 threat context, as they are classified as warfighting actors with the potential to connect with transnational terrorist groups. ${ }^{57}$

The core of this epistemic community - its key conceptual innovators - includes people like Robert J. Bunker. Currently an adjunct research professor of the US Army War College's Strategic Studies Institute (SSI), he has published dozens of articles and books on matters of counter-terrorism, counter-insurgency, gangs and drug trafficking. ${ }^{58}$ Other core members of this community include John P. Sullivan, who previously worked as a police officer. Currently a senior fellow at the Center for Advanced Studies on Terrorism, Sullivan is also an adjunct researcher at the Bogotá-based VORTEX Research Group, where he has published on issues such as drug wars and criminal insurgency. ${ }^{59}$

Another particularly influential member of this epistemic community is Max G. Manwaring. A retired research professor of military strategy at SSI, Manwaring served in SOUTHCOM's politico-military directorate and the Defense Intelligence Agency during Latin America's GCW endgame in El Salvador, where he had 'conducted a quantitative study on the variables that determined (or at least were correlated with) success or failure in COIN campaigns since World War II' ${ }^{60}$ Based at SOUTHCOM's Small Wars Operational Requirements Division (SWORD), he

\footnotetext{
${ }^{57}$ Robert Killebrew, 'A Volatile Brew', Small Wars Journal (2008), available at http://smallwarsjournal. com/blog/journal/docs-temp/175-killebre, last access 15 Jan. 2020.

${ }^{58}$ Recent publications include Stephen Sloan and Robert J. Bunker (eds.), Red Teams and Counterterrorism Training (Norman, OK: University of Oklahoma Press, 2011); Robert J. Bunker and John P. Sullivan (eds.), Studies in Gangs and Cartels (Abingdon: Routledge, 2013); Robert J. Bunker, Criminal Insurgencies in Mexico and the Americas: The Gangs and Cartels Wage War (London: Routledge, 2012); or Narcos Over the Border: Gangs, Cartels and Mercenaries (London: Routledge, 2010).

${ }^{59}$ See, for example, John P. Sullivan, 'From Drug Wars to Criminal Insurgency: Mexican Cartels, Criminal Enclaves and Criminal Insurgency in Mexico and Central America, and their Implications for Global Security', Vortex Working Paper No. 6, March 2012, available at. http://docs.wixstatic.com/ugd/ 522e46_64dcc8cb6b4640209667felacb3ff35f.pdf, last access 15 Jan. 2020.

${ }^{60}$ Kaplan, The Insurgents, p. 158.
} 
developed what later on became known as the 'SWORD model', or 'Manwaring paradigm', in counter-insurgency. ${ }^{61}$ Manwaring's work on the role of legitimacy in counter-insurgency also influenced $F M \quad 3-24 .^{62} \mathrm{He}$ is the author of Street Gangs: The New Urban Insurgency ${ }^{63}$ and recently published a trilogy ${ }^{64}$ that explains how Latin American street gangs, Cuban and Venezuelan popular militias, Argentine piqueteros (picketers) and Mexican cartels turned into actors seeking to 'neutralize, control, depose, or replace an incumbent government' and 'in doing so, radically change the traditional authoritative allocation of values (governance) to the values of the reigning criminal and/or insurgent leaders'. ${ }^{65}$

This actor-network has a node that associates all of the above-mentioned people as well as other core members of this epistemic community who gave life to the criminal insurgency concept: the SWJ's El Centro initiative, a website dedicated to the 'analysis and discussion of Latin America's guerrilla wars and criminal insurgencies' ${ }^{66}$ The website presents the initiative with the following words: 'El Centro is SWJ's focus on small wars in Latin America. The elephant in the hemispheric room is clearly the epidemic criminal, cartel and gang threat, fueled by a drug and migration economy, rising to the level of local and national criminal insurgencies and a significant U.S. national security risk. ${ }^{97}$

The website offers a reading list on these topics, as well as a list of El Centro fellows. These include the above-mentioned persons, as well as influential Washington-based, Latin America-focused security consultants and policy scholars, such as Douglas Farah, Vanda Felbab-Brown and Robert Killebrew, but also actors from the region. The latter comprise Mexico City-based journalist Ioan Grillo, author of El Narco: Inside Mexico's Criminal Insurgency, ${ }^{68}$ and Robert Muggah, founder of the influential Brazilian think tank Igarapé Institute. In a recent article (co-authored with Sullivan), Muggah observed that 'today's warriors are just as likely to be affiliated with drug cartels, mafia groups, criminal gangs, militias, and terrorist organizations as with armies or organized rebel factions'. The resulting

\footnotetext{
${ }^{61}$ See Max G. Manwaring, A Model for the Analysis of Insurgencies (Washington, DC: BDM Management Services, 1988).

${ }^{62}$ Edwin G. Corr, 'Foreword', in Max G. Manwaring, Gangs, Pseudo-Militaries, and Other Modern Mercenaries: New Dynamics in Uncomfortable Wars (Norman, OK: University of Oklahoma Press, 2010), pp. xi-xii; Kaplan, The Insurgents, pp. 157-8. See also John A. Nagl's endorsement on the jacket of Manwaring, Gangs, Pseudo-Militaries, and Other Modern Mercenaries.

${ }^{63}$ Max G. Manwaring, Street Gangs: The New Urban Insurgency (Carlisle, PA: US Army War College, 2005).

${ }^{64}$ Max G. Manwaring, Insurgency, Terrorism, and Crime: Shadows from the Past and Portents for the Future (Norman, OK: University of Oklahoma Press, 2008); Gangs, Pseudo-Militaries, and Other Modern Mercenaries; The Complexity of Modern Asymmetric Warfare (Norman, OK: University of Oklahoma Press, 2012).

${ }^{65}$ Manwaring, The Complexity, p. 103.

${ }^{66}$ For an earlier analysis of El Centro and the application of this framing to Guatemala, see Markus Hochmüller and Markus-Michael Müller, 'Locating Guatemala in Global Counterinsurgency', Globalizations, 13: 1 (2016), pp. 94-8.

${ }^{67}$ See http://smallwarsjournal.com/elcentro, last access 15 Jan. 2020.

${ }^{68}$ Ioan Grillo, El Narco: Inside Mexico's Criminal Insurgency (New York: Bloomsbury, 2012).
} 
'cocktail of criminality, extremism, and insurrection', in turn, would require a 'comprehensive approach' that recognises 'crime wars as wars'. ${ }^{69}$

Such fellows are presented as people who 'have expertise in and commitment to Latin America, support SWJ's particular focus on the small wars in the region, and agree with SWJ's general approach to advancing discussion and awareness in the field through community dialog and publishing'. From the analytical perspective of this article, these actors can be perceived as people who share the SWJ's epistemic worldview. Accordingly, affiliation with El Centro can be seen as a membership card for this epistemic community and a commitment to its 'policy enterprise' of developing 'a better understanding of the national and regional challenges underlying past, present, and future small wars' in Latin America ${ }^{70}$ - particularly through conceptual work, the related adjustment of the actors' discursive behaviour and resulting conceptual cross-referential intensity. All of this is centred on, recall, the reframing of contemporary Latin American security issues through the conceptual lens of 'criminal insurgencies'. A widely cited SWJ article on Mexico provides the following definition:

In describing cartel operations as a criminal insurgency, we do not suggest that the cartel structures are operating a unified operation against the Mexican state. [...] We also do not mean to suggest that the goal of the criminal insurgent, like that of both classical and modern political insurgents - $[s i c]$ is the removal of foreign forces, the satisfaction of discrete political demands, or regime change. The criminal insurgent is resolutely apolitical; he challenges the will of the state because he seeks to sever its regulatory arms. ${ }^{71}$

Another key feature of these criminal insurgencies, according to several El Centro fellows, is that they are potentially 'interlocking' with terrorism, ${ }^{72}$ thereby transforming 'criminal networks' into 'a gateway for terrorists', ${ }^{73}$ by weaving together '[c]rime, terrorism and insurgency' in 'ways that threaten not just the welfare but also the security of societies in the western hemisphere'. Accordingly, ' $t$ t]he United States must lead a hemisphere-wide effort to confront and defeat the cartels' threat to civil society. ${ }^{74}$

In order to assess the impact of this epistemic community in line with the analytical framework developed above, it is instructive to trace the reappearance of the conceptual underpinnings of this epistemology in official policy discourses as

\footnotetext{
${ }^{69}$ Robert Muggah and John. P. Sullivan, 'The Coming Crime Wars', Foreign Policy, 21 Sept. 2018.

${ }^{70}$ See http://smallwarsjournal.com/elcentro, last access 15 Jan 2020.

${ }^{71}$ John P. Sullivan and Adam Elkus, 'State of Siege: Mexico's Criminal Insurgency', Small Wars Journal, available at http://smallwarsjournal.com/jrnl/art/state-of-siege-mexicos-criminal-insurgency, last access 15 Jan. 2020.

${ }^{72}$ See, for example, Sullivan, 'From Drug Wars to Criminal Insurgency'; John P. Sullivan and Robert J. Bunker 'Cartel Evolution Revisited: Third Phase Cartel Potentials and Alternative Futures in Mexico', Small Wars and Insurgencies, 21: 1 (2010), pp. 35-6, 44.

${ }^{73}$ Devin M. Henry, 'Criminal Networks: A Gateway for Terrorists', Small Wars Journal, available at http://smallwarsjournal.com/jrnl/art/criminal-networks-a-gateway-for-terrorists, last access 15 Jan. 2020.

${ }^{74}$ Robert Killebrew and Jennifer Bernal, Crime Wars: Gangs, Cartels and US National Security (Washington, DC: Center for a New American Security, 2010), p. 6.
} 
evidence of policy actors' discursive adjustments to the community's worldview. In turn, this requires an assessment of policy actors' interests in recasting Latin America's security issues through the epistemological prism provided by this actor-network.

\section{Epistemological Resonances}

By the mid-2000s, several developments in the United States - cutting across global, regional, domestic and policy dynamics while connecting past lessons with contemporary needs - intersected, creating a nascent opportunity structure that gave increasing authority and legitimacy to this epistemic worldview in the US security and foreign policy community by recasting Latin American security problems, and possible solutions, in (counter)terrorism and (counter)insurgency terms.

First, and embedded in the DoD's growing policy influence as well as SOUTHCOM's post-9/11 resurgence, there was the Bush administration's positive re-evaluation of the US 'small footprint' counter-insurgency effort during El Salvador's civil war (1980-92), which increasingly became seen as a success in counter-insurgency-driven democratisation, state-building, and human rights protection that could be turned into a model for the campaigns in the GWOT. ${ }^{75}$ Stated otherwise, it was now acceptable to talk positively about Cold War counterinsurgencies in Latin America as successful militarised nation-building efforts with a democratising potential. Second, and around the same time, US domestic security issues, including immigration and border security, became reframed as terrorism-centred homeland security topics. This process was accompanied by a growing awareness of the potential dangers and opportunities the US southern border represents regarding transnational homeland security threats, such as illegal immigration, transnational gang activities, drug trafficking and their convergence with terrorism. ${ }^{76}$ Third, this awareness, in turn, overlapped with the mediatised escalation of the Mexican drug war - early on presented by Mexican President Felipe Calderón Hinojosa (2006-10) as a fight against 'delinquency and terrorism ${ }^{\text {,77 }}$ connected with growing fears regarding the potential risk of state failure in Mexico and elsewhere in the region. ${ }^{78}$ Fourth, there was the more general GWOT-related renaissance of counter-insurgency, including derived concepts, to which the SWJ community already contributed by establishing the journal as an authoritative source of practical guidance.

In this context, post-9/11 counter-insurgency concepts, ideas about 'convergences', and derived militarised solutions, for many people within the US security and foreign policy establishments, offered a promising way to recast the ways hemispheric security could be improved by countering Latin American 'criminal insurgencies' - in particular because of the more than meagre results of less militarised

\footnotetext{
${ }^{75}$ Russell Crandall, The Salvador Option: The United States in El Salvador, 1977-1992 (New York: Cambridge University Press, 2016).

${ }^{76}$ This argument is developed in Müller, 'Punitive Entanglements', pp. 711-13.

${ }^{77}$ 'Masivo envío de invitaciones a la fiesta por la toma de Calderón’, La Jornada, 26 Nov. 2006.

${ }^{78}$ US Joint Forces Command, The Joint Operating Environment 2008 (Suffolk, VA: US Joint Forces Command Center for Joint Futures, 2008); Michael Miklaucic, 'An Interview with General John Kelly', PRISM, 5: 4 (2014), pp. 208-9.
} 
forms and framings of Latin American security governance, notwithstanding decades-long US support ${ }^{79}$ and growing concerns about the possible presence of transnational terrorism in Latin America. In turn, this process could build on, while also amplifying, the immediate post-9/11 framing of FARC as a drug-funded terrorist organisation by the Colombian government and the Bush administration (see below), enabling the US government to legitimise the narcoguerrilla concept and redirect counter-narcotics aid towards counter-terrorism efforts, which, in turn, took on an increasing counter-insurgency outlook. ${ }^{80}$

These overlapping developments provided this epistemic community with all the previously mentioned requirements for successfully promoting their own worldview to a policy audience in search of security 'success stories'. They popularised their perspectives and concepts in policy reports and publications, as well as testimonies in several post-9/11 related committee hearings for the US Congress and Senate. These hearings, in particular, became a platform for reiterating the community's epistemic worldview to a broader policy audience outside the journal's main practitioner audiences. For example, in 2014, at a hearing before the US House Foreign Affairs Committee on Terrorism, Nonproliferation and Trade, Farrah described FARC as 'a prototype of the coming hybrid terrorist-criminal insurgencies', whose operational environment (OE) has been created by states like 'Venezuela, Nicaragua, Bolivia and Ecuador', which enabled 'the FARC, Hezbollah, Iranian officials, ETA, Brazilian drug trafficking organizations and others [to] meet in safety, exchange lessons learned and build networks of convenience, ${ }^{81}$

A few years earlier, in 2011, Felbab-Brown, in a written statement for a hearing before the Subcommittee on Western Hemisphere, Peace Corps and Global Narcotic Affairs, argued that ' $\mathrm{t}$ ] he penetration of the illicit economies by terrorist or insurgent groups provides an especially potent threat to states and regional stability since belligerent groups typically seek to eliminate the existing state's presence in particular locales or countries'. ${ }^{82}$ To counter this threat, she proposed a populationcentric counter-insurgency approach to counter drug trafficking in the region by 'directly defeating the belligerents and protecting the population'. ${ }^{83}$ A few months later, Bunker was invited to give testimony at a joint hearing before the Subcommittee on the Western Hemisphere on the Mérida Initiative. On this occasion, Bunker made a policy recommendation that reiterated the above-mentioned epistemic worldview by placing Latin America in the post-9/11 security context:

\footnotetext{
${ }^{79}$ See, for example, Brian Bow, 'Beyond Mérida? The Evolution of the U.S. Response to Mexico's Security Crisis', in Brian Bow und Arturo Santa-Cruz (eds.), The State and Security in Mexico: Transformation and Crisis in Regional Perspective (New York: Routledge, 2013), p. 77.

${ }^{80}$ Roberto Toledo, 'How Congress Has Legitimated Latin American Counter-Insurgency', Peace Review, 16: 4 (2004), p. 503.

${ }^{81}$ Testimony of Douglas Farah before the House Foreign Affairs Subcommittee on Terrorism, Nonproliferation and Trade, 4 Feb. 2014. See www.govinfo.gov/content/pkg/CHRG-113hhrg86587/pdf/ CHRG-113hhrg86587.pdf, last access 28 Feb. 2020.

${ }^{82}$ Vanda Felbab-Brown, 'Written Testimony Prepared for the Hearing before the Subcommittee on Western Hemisphere, Peace Corps and Global Narcotic Affairs, A Shared Responsibility: Counternarcotics and Citizen Security in the Americas' (Washington, DC: Government Printing Office, 2011), p. 31.

${ }^{83}$ Ibid., p. 33.
} 
Due to the evolution of the cartels and gangs into new warmaking entities [... ], the Merida [sic] Initiative and others like it directed at Colombia and Central America need to evolve to a more encompassing scope and scale and with a greater sense of strategic urgency than most congressional policymakers might a priori think is necessary. Following the 10-year anniversary of 9/11, the key strategic insight that I offer is this: [...] The cartels and narco-gangs of the Americas, with those in Mexico of the highest priority, must now be elevated to the number one strategic threat to the United States. ${ }^{84}$

Statements like these, together with the underlying conceptual work of the epistemic community, increasingly informed post-9/11 budgetary activities, legal initiatives and security assistance towards Latin America. For example, in 2011, Bill H.R. 3401 was proposed by the chairperson of the Subcommittee on the Western Hemisphere, Connie Mack. Named the Enhanced Border Security Act, the bill reiterates the convergent threat scenario by calling for the application of 'counterinsurgency tactics under a coordinated and targeted strategy to combat the terrorist insurgency in Mexico waged by transnational criminal organizations' ${ }^{85}$ One year earlier, when the Obama administration had already included the crime-terror-insurgency nexus into its official strategy, ${ }^{86}$ then-US Secretary of State Hillary Clinton stated that 'we face an increasing threat from a well-organized network drug trafficking threat that is, in some cases, morphing into or making common cause with what we would consider an insurgency in Mexico and in Central America, ${ }^{87}$ And the US embassy in Brazil posted on its website a White House statement on the topic, which argued that ' $[t]$ errorists and insurgents increasingly are turning to TOC [transnational organised crime] to generate funding and acquire logistical support to carry out their violent acts', thereby contributing to 'the convergence of threats that were once distinct and today have explosive and destabilizing effects' ${ }^{88}$

By that time, and despite the fact that the empirical evidence for the scope and actual impact of these convergences seems rather weak - with publications often being speculative, under-referenced, and heavily reliant on media reports as well as official sources pointing towards 'possible' or 'alleged' connections ${ }^{89}$ - the

\footnotetext{
${ }^{84}$ US Congress, Joint Hearing before the Subcommittee on the Western Hemisphere, 'Has Mérida Evolved? Part One: The Evolution of Drug Cartels and the Threat to Mexico's Governance' (Washington, DC: US Government Printing Office, 2011), p. 24.

${ }^{85}$ Available at www.gpo.gov/fdsys/pkg/BILLS-112hr3401ih/html/BILLS-112hr3401ih.htm, last access 15 Jan. 2020. See also Hochmüller and Müller, 'Locating Guatemala', p. 100.

${ }^{86}$ President of the United States, Strategy to Combat Transnational Organized Crime. Addressing Convergent Threats to National Security (Washington, DC: The White House, 2011), p. 6.

${ }^{87}$ Secretary of State Hillary Clinton's speech at the Council on Foreign Relations, updated 8 Sept. 2010, available at https://secretaryclinton.wordpress.com/2010/09/08/secretary-of-state-hillary-clintonsspeech-atthe-council-on-foreign-relations, last access 15 Jan. 2020.

${ }^{88} \mathrm{See} \quad \mathrm{https} / / /$ br.usembassy.gov/transnational-organized-crime-growing-threat-national-internationalsecurity/, last access 15 Jan. 2020.

${ }^{89}$ See, for example, Dawn L. Bartell and David H. Gray, 'Hezbollah and Al-Shabaab in Mexico and the Terrorist Threat to the United States', Global Security Studies, 3: 4 (2012), pp. 100-14; Duncan Deville, 'The Illicit Supply Chain', in Miklaucic and Brewer (eds.), Convergence, p. 71; Vanessa Neumann, 'The New Nexus of Narcoterrorism: Hezbollah and Venezuela', Foreign Policy Research Institute E-Notes (Dec. 2011), available at www.fpri.org/docs/media/201112.neumann.narcoterrorism.pdf, last access 15 Jan.
} 
post-9/11 security epistemology also started to appear in US security assistance programmes towards the region. For example, the DoD-funded Haiti Stabilization Initiative implemented a 'community counterinsurgency' programme in support of the United Nations Stabilization Mission in Haiti (MINUSTAH), which made efforts to confront the "criminal insurgency'90 waged by local street gangs and other non-state, armed actors, who were also framed as terrorists by the Haitian government and the UN bureaucracy. ${ }^{91}$

Another example of this is USAID's incorporation of FM 3-24 concepts, such as the clear-hold-build (C-H-B) approach, ${ }^{92}$ into community policing schemes of the Central American Security Initiative (CARSI). ${ }^{93}$ In fact, many post-9/11, US-driven security cooperation programmes with Latin America through initiatives such as CARSI, the Mexico-centred Mérida Initiative, Plan Colombia or the Andean Regional Initiative, the latter of which is an expanded version of Plan Colombia, are marked by the growing recognition that, in the words of a former advisor to the Bush administration, 'the U.S. cannot continue to make a false distinction between counterinsurgency and counter-narcotics efforts' ${ }^{94}$ Accordingly, US security aid channelled through these initiatives includes a strong counterinsurgency focus, often framed as 'stabilisation' (see below). ${ }^{95}$

These initiatives are an integral element of a worldwide expansion of post-9/11 US security assistance programmes that aim at capacity building of local partner forces, notably in the realms of 'counterterrorism, counternarcotics, and defense institution building, ${ }^{96}$ Accordingly, US security assistance programmes doubled

2020; George Washington University Homeland Security Policy Institute and the Center for Strategic Leadership, US Army War College (eds.), The Hybrid Threat: Crime, Terrorism and Insurgency in Mexico (Washington, DC, 2011); Celina B. Realuyo, 'The Terror-Crime Nexus: Hezbollah's Global Facilitators', PRISM, 5: 1 (2014), pp. 117-31. For a rare academic analysis, see Thomaz G. Costa and Gastón H. Schulmeister, 'The Puzzle of the Iguazu Tri-Border Area: Many Questions and Few Answers Regarding Organised Crime and Terrorism Links', Global Crime, 8: 1 (2007), pp. 26-39. Even the DoS' 2017 Country Reports on Terrorism states that while 'many Latin American countries have porous borders, limited law enforcement capabilities, and established smuggling routes', which 'offer opportunities to foreign terrorist groups [...] there have been no cases of terrorist groups exploiting these gaps to move operations through the region [the Western Hemisphere]'. See www.state.gov/reports/country-reports-onterrorism-2017/, last access 15 Jan. 2020.

${ }^{90}$ David C. Becker, 'Gangs, Netwar and “Community Counterinsurgency” in Haiti', PRISM, 2: 3 (2010), pp. 137, 151.

${ }^{91}$ Markus-Michael Müller and Andrea Steinke, 'The Geopolitics of Brazilian Peacekeeping and the United Nations' Turn Towards Stabilisation in Haiti', Peacebuilding, 8: 1 (2020), pp. 54-77.

${ }^{92} \mathrm{C}-\mathrm{H}-\mathrm{B}$ first aims at destroying/expulsing insurgents, followed by the permanent deployment of a security force, and, ultimately, the improvement of living conditions through social-service delivery, see FM 3-24, 5-51-5-80.

${ }^{93}$ Hochmüller and Müller, 'Locating Guatemala', p. 103.

${ }^{94}$ Quoted in Michael L. Evans, 'U.S. Drug Policy and Intelligence Operations in the Andes', Institute for Policy Studies, available at https://ips-dc.org/us_drug_policy_intelligence_operations_in_the_andes/, last access 15 Jan. 2020.

${ }^{95}$ María José Rodríguez Rejas, La norteamericanización de la seguridad en América Latina (Mexico City: Akal, 2017); Sebastián Albuja, 'Stabilization Next Door: Mexico's US-backed Security Intervention', in Robert Muggah (ed.), Stabilization Operations, Security and Development: States of Fragility (Abingdon: Routledge, 2014), pp. 167-81.

${ }^{96}$ Susan B. Epstein and Lina W. Rosen, U.S. Security Assistance and Security Cooperation Programs: Overview of Funding Trends (Washington, DC: Congressional Research Service, 2018), p. 2. 
from 57 in 2001 to 117 in 2017, totalling US\$20 billion. While the majority of this money is earmarked for initiatives in Africa, the Middle East, Iraq and Afghanistan, 78 of these programmes can operate in Latin America and the region received US $\$ 20.5$ billion in security assistance during this period. ${ }^{97}$ Nearly US $\$ 3.6$ billion of this assistance has been provided by the DoD through Section 1004 of the National Defense Authorization Act for Fiscal Year (FY) 1998 and Section 1033 of the National Defense Authorization Act for FY 1998, ${ }^{98}$ both of which provide the DoD with a counter-narcotics budget that can be used for equipping, training and supporting other countries' counter-narcotic activities. Additionally, and specifically targeting Colombia, Section 1021 of the National Defense Authorization Act for FY 2005 provides the DoD with funds 'to support a unified campaign by the Government of Colombia against narcotics trafficking and against activities by organizations designated as terrorist organizations', which include insurgent groups like FARC and ELN, as well as Autodefensas Unidas de Colombia (United Self-Defence Forces of Colombia). ${ }^{99}$

Likewise, the DoD's counter-narcotics strategy acknowledges that 'the potential nexus among illegal traffickers, terrorists, and insurgents is becoming a commonly recognized national security threat'. ${ }^{100}$ For confronting such 'hybrid criminalterror-insurgent threats', the DoD seeks to link its fight against TOC to 'other national security priorities', such as 'counterterrorism'. ${ }^{101}$ This includes Latin America. Reflecting the placement of the region within the GWOT, the DoD's counter-narcotics efforts explicitly seek to 'disrupt the nexus between illicit drugs and foreign terrorist organizations operating in and from South and Central America, focusing on linkages with the Middle East and Africa'. ${ }^{102}$

Although these developments demonstrate how much the crime-terror-insurgency nexus epistemology is shaping contemporary US security assistance programmes towards Latin America, in order to fully uncover the southwards travel of this security epistemology, Latin American actors and their interests in incorporating this epistemology into local security discourses and policies need to be assessed.

\section{Embracing the Nexus}

After the issuing of National Security Council Resolution 5432/1 in 1954, which called for ' $[t]$ he ultimate standardization of Latin American military organization, training, doctrine and equipment along U.S. lines', ${ }^{103}$ the GCW produced deep

\footnotetext{
${ }^{97}$ See www.wola.org/analysis/u-s-military-assistance-latin-america/, last access 15 Jan. 2020.

${ }^{98}$ See https://securityassistance.org/fact_sheet/us-counternarcotics-programs-latin-america, last access 15 Jan. 2020.

${ }^{99}$ See https://defenseoversight.wola.org/program/108, last access 15 Jan. 2020.

${ }^{100}$ US Department of Defense, Counternarcotics and Global Threats Strategy (Washington, DC: 2010), p. 5.

${ }^{101}$ William F. Wechsler and Gary Barnabo, 'The Department of Defense's Role in Combating Transnational Organized Crime', in Miklaucic and Brewer (eds.), Convergence, pp. 235, 241.

${ }^{102}$ DoD, Counternarcotics, p. 15.

${ }^{103}$ 'Statement of Policy by the National Security Council, United States Objectives and Courses of Action with respect to Latin America', 3 Sept. 1954, in Foreign Relations of the United States 1952-1954, vol. 4 (Washington, DC: US Government Printing Office, 1983), p. 82.
} 
entanglements between the United States and most Latin American militaries through doctrinal input and practical advice, specifically in the area of counterinsurgency. ${ }^{104}$ These entanglements survived the end of the GCW and they were revived with the increasing militarisation of the war on drugs by the administration of George Bush Sr., ${ }^{105}$ and, in particular, 9/11.

Examining currently valid Latin American military doctrine is particularly instructive for understanding the ongoing relevance of such entanglements as well as for following the travels of the 'convergence'-centred security epistemology 'down south' by tracing the reappearance of related concepts in Latin American military doctrine.

\section{Doctrinal Entanglements}

Military doctrine is the medium through which military knowledge production as well as the concepts informing it get translated into practice. Doctrine defines an 'approved set of principles and methods, intended to provide large military organizations with a common outlook and a uniform basis for action'. ${ }^{106}$ Doctrinal publications are shaped by internal stimuli, such as institutional cultures and previous military experiences, as well as by external influences. ${ }^{107}$ Regarding the latter, it is important to recognise that militaries are inherently transnational institutions, embedded in the circulation of personnel, doctrine and practices across countries and regions. ${ }^{108}$ Military doctrine, in this regard, is a prime example of global policy mobility and the simultaneity of transfer and translation processes regarding the localisation of externally provided epistemologies.

In order to understand why Latin American militaries translated the convergencecentred security epistemology into local military doctrine, it has to be recalled that while most of the region's armed forces have decades-long counter-insurgency experience, their leading role in the region's GCW fight against 'subversion', as well as the resulting human rights violations, was also the main source for international and domestic criticisms. Accordingly, the return to civilian rule implied efforts to demilitarise security governance and downsize military budgets, as well as enhance civilian control over the militaries. ${ }^{109}$

Tapping into the post-Cold War drug war discourse during the 1990s offered some kind of substitute for 'weakened' militaries in the Americas by providing ongoing material support as well as a 'visceral image of an utterly evil adversary'

\footnotetext{
${ }^{104}$ See, for example, Lesley Gill, The School of the Americas: Military Training and Political Violence in the Americas (Durham, NC: Duke University Press, 2004); Martha K. Huggins, Political Policing: The United States and Latin America (Durham, NC: Duke University Press, 1998).

${ }^{105}$ Carpenter, Bad Neighbor Policy, pp. 33-58.

${ }^{106}$ Daniel Moran, 'Doctrine, Military', in Richard Holmes (ed.), The Oxford Companion to Military History (New York: Oxford University Press, 2001), p. 262.

${ }^{107}$ Keith B. Bickel, Mars Learning: The Marine Corps' Development of Small Wars Doctrine, 1915-1940 (Boulder, CO: Westview Press, 2001), pp. 4, 8-12.

${ }^{108}$ See, for example, Walter Bruyère-Ostells and François Dumasy (eds.), Pratiques militaires et globalisation, XIXe-XXIe siècles (Paris: Bernard Giovanangeli, 2014); Tarak Barkawi, Globalization and War (Lanham, MD: Rowan and Littlefield, 2006).

${ }^{109}$ David E. Spencer, 'Post-Cold War Insurgency and Counterinsurgency in Latin America', in Rich and Duyvesteyn (eds.), The Routledge Handbook of Insurgency and Counterinsurgency, p. 240.
} 
designating the drug cartels. ${ }^{110}$ While this also allowed for some counterinsurgency practices to survive under drug war frameworks and specially trained counter-narcotics units, overall counter-insurgency was marginalised, although it never disappeared, in post-Cold War Latin America.

Against this background, strategically harnessing the post-9/11 security epistemology can be seen as a way of countering this marginalisation through an upgrading recycling, or 'upcycling', of already-existing counter-insurgency capacities. As the crime-terror-insurgency nexus discourse elevates criminal actors beyond the realm of ordinary lawlessness by portraying them as a military/terrorist threat, embracing this epistemology allows for a rebranding of law enforcement/public security issues as military/national security problems. In turn, in adjusting their discursive behaviour, Latin American militaries can strengthen/regain their legitimacy as domestic security actors by portraying themselves as the institutions capable of confronting the region's 'crime wars' and their potential convergence with terrorism. Following from this, the rebranding calls for 'new rules of engagement', ${ }^{111}$ justifies increased military expenditures ${ }^{112}$ to confront threats from gangs, insurgents and drug cartels, ${ }^{113}$ and requires more counter-insurgency and counter-terrorismfocused domestic security responses and expertise. ${ }^{114}$ The latter is not only deemed necessary due to the potential links between criminals, insurgents and transnational terrorists, but also because the violence of the former is increasingly framed by Latin American security analysts and practitioners through a terrorism lens. ${ }^{115}$

Taking a closer look at newly issued military doctrine from Brazil and Colombia the two countries with the highest military expenditures in the region ${ }^{116}$ - illustrates

\footnotetext{
${ }^{110}$ Carpenter, Bad Neighbor Policy, p. 49.

${ }^{111}$ Muggah and Sullivan, 'The Coming Crime Wars'.

${ }^{112}$ According to the Stockholm Institute for Peace Research (SIPRI)'s Military Expenditure Database, the region's military budgets (for South America, Central America and the Caribbean), measured by constant 2017 exchange rates, only 'modestly' increased from US $\$ 33.9$ billion in 1990 to US $\$ 36.5$ billion in 2000 . This trend reversed after 9/11, with region-wide military expenditures increasing from US $\$ 44.6$ billion in 2001 to US $\$ 68.1$ billion in 2018. See www.sipri.org/sites/default/files/Data\%20for\%20world\%20regions \%20from\%201988-2018\%20\%28pdf\%29.pdf, last access 15 Jan. 2020.

${ }^{113}$ 'Top Eight Countries Dominate Defense Spending in Latin America', Defense and Security Monitor, 20 March 2017, available at https://dsm.forecastinternational.com/wordpress/2017/03/20/eight-countriesdominate-defense-spending-in-latin-america/, last access 15 Jan. 2020.

${ }^{114}$ This includes in particular the region's Special Operation Forces that, since 2004, have been regularly participating in joint training exercises within the Fuerzas Comando military competition framework, sponsored by SOUTHCOM, in order to enhance their counter-terrorism capacities by practicing GWOT tactics and methods. 'Colombia, Ecuador y Costa Rica ganan competencia contra terrorismo', La Prensa, 28 June 2007. See also www.southcom.mil/Media/Special-Coverage/Fuerzas-Comando-2017/, last access 15 Jan. 2020.

${ }^{115}$ Gerardo Rodríguez Sánchez Lara and Mario Arroyo Juárez, 'El terrorismo como método del crimen organizado en México', in Raúl Benítez Manaut (ed.), Crimen organizado e Iniciativa Mérida en las relaciones México-Estados Unidos (Mexico City: Colectivo de Análisis de la Seguridad con Democracia, 2010), pp. 87-96; Alvaro de Souza Pinheiro, Irregular Warfare, Brazil's Fight Against Criminal Urban Guerrillas (MacDill Air Force Base, FL: Joint Special Operations University, 2012); Eduardo de Oliveira Fernandes, 'As ações terroristas do crime organizado no Brasil', Defesanet, 5 Dec. 2016, available at www.defesanet.com.br/ terror/noticia/24246/As-acoes-terroristas-do-crime-organizado-no-Brasil/, last Access 15 Jan. 2020.

${ }^{116} \mathrm{~A} 2019$ SIPRI study ranks Brazil and Colombia as having the world's $12^{\text {th }}$-highest and $25^{\text {th }}$-highest military expenditures respectively. See www.sipri.org/publications/2019/sipri-fact-sheets/trends-world-militaryexpenditure-2018. After 9/11, Brazil's military expenditures, measured by constant 2017 US\$, increased from
} 
this 'upcycling' of local military doctrine through a re-articulation of domestic counter-insurgency experiences with the post-9/11 security epistemologies and concepts discussed above.

From the mid-2000s onwards, Brazil sought to adapt its defence strategy to the realities of a GWOT-shaped global OE. For example, in 2005, the Brazilian Defence Ministry stated that 'non-governmental actors, new threats and the opposition between nationalism and transnacionalism [sic] permeate international affairs and the security arrangements of States'. Accordingly, 'transnational crimes of different nature and international terrorism' have turned into 'menaces to peace, to security and democratic order' ${ }^{117}$ In order to adapt to these changes, Brazil's military embarked on a doctrinal renewal process. In line with the 'improvement' and deepening of US-Brazil defence cooperation under the Lula da Silva (2003-11) and Rousseff (2011-16) governments, ${ }^{118}$ post-9/11 US doctrine was a key reference in this process for Brazil.

A 2013 presentation by the Centro de Doutrina do Exercito (Brazilian Army Doctrine Centre, CeDoutEx), for instance, opened with quoting parts of a West Point speech by then-US Minister of Defence Robert Gates. In his speech, Gates laid out the future panorama facing the US Army by stating that ' $[\mathrm{w}]$ hat we can expect in the future is that potential adversaries - be they terrorists, insurgents, militia groups, rogue states, or emerging powers - will seek to frustrate America's traditional advantages [...] From the look of things, the Army will not repeat the mistakes of the past, where irregular warfare was shunted to the side after Vietnam.' Accordingly, preparedness for such missions is crucial, as 'from the Mayaguez to Grenada, Panama, Somalia, the Balkans, Haiti, Kuwait, Iraq, and more - we had no idea a year before any of these missions that we would be so engaged'. 119 To avoid having 'no idea' about such engagements, the CeDoutEx presentation outlined the new OE for Brazil's armed forces. In addition to presenting a continuum of the spectres of possible contemporary conflicts, ranging from a 'stable peace' to an 'unstable peace', 'insurgency' and 'total warfare', it portrays the current OE in GWOT terms. For example, by stressing the role of the 'human terrain', ${ }^{120}$ the presence of 'new actors', and its 'selective lethality'. ${ }^{121}$

One year later, with the publication of the Brazilian Army's Land Warfare Manual (EB20-MF-10.102), these reflections were turned into military doctrine. EB20-MF-10.102 lays out the country's post-9/11 threat scenario, both domestic

19.339 million in 2000 to 30.679 million in 2018. Colombia's military expenditures rose from 4.859 million in 2000 to 10.303 million in 2018. See www.sipri.org/sites/default/files/Data\%20for\%20all\%20countries\%20from \%201988-2018\%20in\%20constant\%20\%282017\%29\%20USD\%20\%28pdf\%29.pdf.

${ }^{117}$ See www.oas.org/csh/english/documents/Brazil_English\%202005.doc, last access 4 March 2020.

${ }^{118}$ Luis Bitencourt, Brazilian Military Culture 2018 (Miami, FL: Florida International University, Jack D. Gordon Institute for Public Policy and Kimberly Green Latin American and Caribbean Center, 2018), p. 25. For US-Brazilian military cooperation in Haiti, see also Müller and Steinke, 'Geopolitics'.

${ }^{119}$ See https://archive.defense.gov/Speeches/Speech.aspx?SpeechID=1539, last access 15 Jan. 2020.

${ }^{120}$ On 'human terrain', see Roberto J. González, 'Ethnographic Intelligence: The Human Terrain System and Its Enduring Legacy', in Louise Wiuff Moe and Markus M. Müller (eds.), Reconfiguring Intervention: Complexity, Resilience and the "Local Turn" in Counterinsurgent Warfare (London: Palgrave Macmillan, 2017), pp. 51-74.

${ }^{121}$ Exército Estado-Maior, Centro de Doutrina Terrestre, 'Doutrina militar terrestre: Novos conceitos', available at http://bdex.eb.mil.br/jspui/handle/123456789/287, last access 15 April 2020. 
and international, in the following way: 'The growing significance of transnational groups or insurgents, with or without political and material support from other countries, amplifies the diffuse nature of the threats to be countered by the use of the defence forces. ${ }^{122}$ And in defining the OE to be navigated by a Força Terrestre Componente (Land Force Component, FTC), it states:

The complex environment in which a FTC operates contains a multiplicity of actors which, in an integrated way and under certain conditions, can constitute a hybrid threat. This type of threat unites the underlying dynamics of, even if diverse, regular and irregular forces, searching to attain mutually beneficial goals. In some cases, this type of threat can include terrorist cells and/or criminals. ${ }^{123}$

Moreover, the Brazilian military's recently published Pacification Field Manual $(E B-20-M C-10.217)^{124}$ - which defines and formalises the military's role in international and domestic pacification operations and whose reference materials include FM 3-24 and the controversial Human Terrain Handbook, as well as several NDU and Military Review publications on counter-insurgency and stability operations - introduces key post-9/11 counter-insurgency ideas. These include the 'protecting the people' mantra, ${ }^{125}$ the C-H-B approach, ${ }^{126}$ and the centrality of knowing, navigating and controlling the 'human terrain'. ${ }^{127}$ By integrating these concepts derived from post-9/11 US military doctrine, the manual explicitly seeks to upgrade Brazil's long domestic experience with pacification, which, as is rightly stressed, dates back to the nineteenth century, ${ }^{128}$ to the 'complexities of the contemporary operational environment'. ${ }^{129}$ These complexities, as the preceding quote from EB20-MF-10.102 makes clear, are marked by 'hybrid' threats that echo the crime-terror-insurgency nexus.

The Colombian military's recently published Damascus Doctrine is even more explicit. Even though no new counter-insurgency manual has been published due to the negative attention the country's military has received because of its counter-insurgency outlook, ${ }^{130}$ ideas of 'convergences' as well as the crime-terror-insurgency nexus loom large in Colombia's 'post-conflict' military doctrine, which, again, has been greatly influenced by post-9/11 US doctrine and underlying epistemologies. In fact, as Colonel Pedro Javier Rojas Guevara, the director of the Centro de Doctrina del Ejército Nacional stated, currently valid post-9/11 US doctrine "has been the model for the "Damascus" project, with which the Colombian Army seeks to generate and adapt its doctrine to the contemporary and future

\footnotetext{
${ }^{122}$ Ministerio de Defensa, Exército Brasileiro, Estado-Maior do Exército, Manual de Fundamentos, Doutrina Militar Terrestre EB20-MF-10.102, Brasilia, 2014, 4.6.1.4.2.

${ }^{123}$ Ibid., 7.5.4.

${ }^{124}$ Ministerio de Defensa, Exército Brasileiro, Estado-Maior do Exército, Manual de Campanha EB-20-MC-10.217 Operações de Pacificação, Brasilia, 2015, 4.6.1.4.2.

${ }^{125}$ EB-20-MC-10.217, 2.5.5.1.

${ }^{126}$ Renamed 'Intervention-Stabilisation-Normalisation', ibid., 2.5.5.5.

${ }^{127}$ Ibid., 3.4.3.7, 4.3.10.1.

${ }^{128}$ Ibid., 1.2.1.

${ }^{129}$ Ibid., 1.2 .2

${ }^{130}$ Pedro Javier Rojas Guevara, 'Doctrina Damasco: eje articulador de la segunda gran reforma del Ejército Nacional de Colombia', Revista Científica General José María Córdova, 15: 9 (2017), p. 98.
} 
social, economic, political and geostrategic conditions, until 2030'. ${ }^{131}$ Colombia's stabilisation manual (MFRE 3-07 Estabilidad) ${ }^{132}$ is even numerically named after FM 3-07 Stability Operations, ${ }^{133}$ which can be seen as an updated version of FM 3-24 for the 'small footprint' era (see below). ${ }^{134}$

MFRE 3-07 considers stability operations as being inherently related to counterinsurgency. It advises counter-insurgents to 'take into account the history of [Colombia's] internal conflict that has demonstrated that insurgent groups show a strong tendency to associate with and execute delinquent activities (including transnational crimes, such as drug trafficking, illegal arms trafficking, and illegal mining) [...] This, in general, has the consequence that these groups convert themselves into hybrid threats with a higher warfighting capacity. ${ }^{, 135}$ Echoing Brazil's EB20-MF10.102 , a 'hybrid threat' is defined as 'the dynamic and diverse combination of regular and irregular forces, terrorist forces and/or criminal elements united to achieve mutual benefits'. ${ }^{136}$ In order to counter such 'irregular threats', the following five operations, either 'as a sequence, in parallel or in combination', need to be executed:

- Counterterrorism.

- Unconventional Warfare.

- Foreign Internal Defence (for external operations).

- Counterinsurgency.

- Stabilisation Tasks. ${ }^{137}$

While Brazilian and Colombian military doctrine thus incorporated basic post-9/11 security epistemologies and concepts, this did not happen through a simple doctrinal transfer from the United States. Rather, it resulted from an upcycling process that combined epistemological borrowings from abroad with long-standing domestic counter-insurgency experiences (for example, the references to Brazil's long pacification experience and Colombia's internal conflict) - experiences that were the product of earlier forms of epistemological transfer and translation. ${ }^{138}$

The strong local interests behind this development can be further illustrated with regards to the third of the above-mentioned operations - 'Foreign Internal Defence', another conceptual borrowing from US doctrine. ${ }^{139}$ This term indicates

\footnotetext{
${ }^{131}$ Ibid., p. 101, emphasis added.

${ }^{132}$ Ejército Nacional de Colombia, Manual Fundamental de Referencia del Ejército, MFRE 3-07 Estabilidad (Bogotá, 2017).

${ }^{133}$ US Army, FM 3-07 Stability Operations (Washington, DC: Headquarters, Department of Army, 2008).

${ }^{134}$ Hodge, Armed Humanitarians, pp. 14-17.

${ }^{135}$ MFRE 3-07, 3.8 [3-133].

${ }^{136}$ Ejército Nacional de Colombia, Manual Fundamental de Referencia del Ejército, MFRE 3-0 Operaciones (Bogotá, 2017), 1.1.2 [1-14] (original emphasis).

${ }^{137}$ Ibid., 2.3 [2-18].

${ }^{138}$ Huggins, Political Policing; Forrest Hylton, 'Plan Colombia: The Measures of Success', The Brown Journal of World Affairs, 17: 1(2010), pp. 99-115; João Roberto Martins Filho, 'Military Ties between France and Brazil during the Cold War, 1959-1975', Latin American Perspectives, 41 : 5 (2014), pp. 16783; Rodríguez Hernández and Saúl Mauricio, La influencia de los Estados Unidos en el ejército colombiano,1951-1959 (Medellín: La Carreta Editores, 2006).

${ }^{139}$ FM 3-24, 6-5, 6-12.
} 
that, far from being exclusively situated at the receiving end of GWOT-related epistemic 'transfers', countries such as Colombia and Brazil are actively involved in the global circulation of the latter via the export of their upcycled counter-insurgency expertise.

\section{The Import-Export Business of Counter-Insurgency}

After 9/11, Andrés Pastrana Arango's government (1998-2002) successfully managed to 'invite' the United States to intervene in Colombia. This was achieved by linking up with the Bush administration's declaration of a 'war against terrorism': on the one hand, by reframing FARC as a terrorist organisation financed through drug trafficking ${ }^{140}$ - which also provided the Bush administration with an opportunity to demonstrate that its war on terror was not specifically about Islamic terrorism but terrorism in general ${ }^{141}$ - and, on the other hand, by engaging in what Arlene B. Tickner calls a strategic 'self-orientalisation', which presented Colombia as lacking sufficient military and state capacity to tackle this criminal-terroristinsurgency threat in the western hemisphere. The Bush administration 'accepted' this invitation and removed 'the (fuzzy) line between counternarcotics and counterinsurgency/counterterrorism'. In turn, US assistance under a GWOT-revamped Plan Colombia was now used 'to professionalize and modernize the armed forces in their battle against leftist insurgents' - especially under the banner of President Álvaro Uribe Vélez's (2002-10) domestic 'democratic security' policy. ${ }^{142}$ Colombia's military success in weakening FARC after the mid-2000s, culminating in the 2016 peace accord, coincided with a shift in US preferences from 'big footprint' counter-insurgency campaigns towards leaner 'small footprint' stabilisation approaches centred on cooperating with local counter-insurgents, notably Special Operations Forces. Likewise, Colombia was turned into a global model for confronting the crime-terror-insurgency nexus through 'locally owned' counterinsurgency. Notwithstanding substantial human rights violations, as well as the subjugation of police and basic governance functions under counter-insurgency logics, ${ }^{143}$ this model became increasingly promoted by key COINdinistas, ${ }^{144}$ the Obama administration, ${ }^{145}$ and the Colombian government, which sought to exploit the opportunity to reposition itself as a global security exporter. As Uribe's successor Juan Manuel Santos (2010-18) stated in 2015 at a UN peacekeeping conference: 'Colombia has a successful experience in the fight against terrorism, drugtrafficking, insurgency, [and] transnational crime and we are ready to share this

\footnotetext{
${ }^{140}$ Jonathan D. Rosen, The Losing War: Plan Colombia and Beyond (Albany, NY: State University of New York, 2014), p. 50; Arlene B. Tickner 'Associated-Dependent Security Cooperation: Colombia and the United States', in Jana Hönke and Markus-Michael Müller (eds.), The Global Making of Policing: Postcolonial Perspectives (Abingdon: Routledge, 2016), pp. 96-113.

${ }^{141}$ Rosen, The Losing War, p. 50.

${ }^{142}$ Tickner, 'Associated-Dependent Security', pp. 99-100.

${ }^{143}$ Ibid.; Rosen, The Losing War, pp. 68-71; Hylton, 'Plan Colombia'.

${ }^{144}$ Dickie Davis, David Kilcullen, Greg Mills and David Spencer (eds.), A Great Perhaps? Colombia: Conflict and Convergence (London: Hurst, 2016); Moe and Müller, 'Counterinsurgency'.

${ }^{145}$ See https://obamawhitehouse.archives.gov/the-press-office/2013/12/03/fact-sheet-united-states-andcolombia-strategic-partners, last access 15 Jan. 2020.
} 
with the world. ${ }^{, 146}$ In addition to increasing Colombia's international visibility, this export strategy has also provided a solution to the somewhat inevitable downsizing of Colombia's military in the 'post-conflict' context. Sharing Colombian security expertise 'with the world', in this regard, also allows 'for putting this surplus capacity to effective use abroad', ${ }^{147}$ thereby avoiding potential military resistance against post-conflict restructuring.

The means of choice for exporting Colombia's counter-insurgency experience has become the country's 'democratic security diplomacy' as well as its 'International Cooperation Strategy for Integral Security'. Under these labels, Colombia started exporting its expertise in confronting 'terrorism, drug-trafficking, insurgency, [and] transnational crime' abroad, notably to Africa ${ }^{148}$ and Latin America, where, since 2010, Colombian advisors started training security personnel in Costa Rica, Ecuador, El Salvador, Guatemala, Haiti, Honduras, Mexico, Panama and Peru. ${ }^{149}$

Colombia's success on the counter-insurgency front also inspired Brazil. In fact, Rio de Janeiro's pacification programme, in operation since 2008, was initially influenced by the Uribe government's first urban counter-insurgency campaign, Operación Orión, launched in Medellín in 2002. Insights from Medellín travelled back to Rio de Janeiro and from there onwards to Haiti, where - under the umbrella of MINUSTAH and within Brazil's overall strategy of carving out a more visible and influential position in the UN system - Brazilian soldiers, in their fight against the 'criminal insurgency' waged by street gangs, experimented for the first time with the C-H-B approach. ${ }^{150}$

The results of this experience not only travelled back to Brazil, where they fed into doctrinal revision processes and the framing of local gangs as 'insurgents' with potential ties to terrorist groups like Hezbollah and FARC by MINUSTAH veterans such as Brigadier General Roberto Escoto (a 1982 graduate of the Agulhas Negras Military Academy who was also involved in the pacification of the favela Maré and, after he went into reserve ranks in 2016, founded Brazil's

\footnotetext{
${ }^{146}$ See http://wp.presidencia.gov.co/Noticias/2015/Septiembre/Paginas/20150928_08-Colombia-esta-listapara-compartir-con-el-mundo-su-exitosa-experiencia-contra-el-terrorismo-el-narcotrafico.aspx, last access 15 Jan. 2020.

${ }^{147}$ Arlene B. Tickner, Colombia, the United States, and Security Cooperation by Proxy (Washington, DC: WOLA, 2014), p. 5.

${ }^{148}$ Arlene B. Tickner, 'Exportación de la seguridad y política exterior de Colombia’ (Bogotá: Friedrich Ebert Stiftung, 2016); Moe and Müller, 'Counterinsurgency'.

${ }^{149}$ Tickner, 'Exportación', p. 19.

${ }^{150}$ Markus-Michael Müller, 'Entangled Pacifications: Peacekeeping, Counterinsurgency and Policing in Port-au-Prince and Rio de Janeiro', in Hönke and Müller (eds.), Global Making, pp. 77-95; 'Policing as Pacification: Postcolonial Legacies, Transnational Connections and the Militarization of Urban Security in Democratic Brazil', in Michelle Bonner, Michael Kempa, Mary Rose Kubal and Guillermina Seri (eds.), Police Abuse in Contemporary Democracies (Basingstoke: Palgrave Macmillan, 2018), pp. 221-47. See also Connor O’Reilly, 'Branding Rio de Janeiro's Pacification Model: A Silver Bullet for the Planet of Slums?', in Connor O’Reilly (ed.), Colonial Policing and the Transnational Legacy: The Global Dynamics of Policing Across the Lusophone Community (London: Routledge, 2017), pp. 227-52; Christoph Harig, 'Re-Importing the "Robust Turn" in UN Peacekeeping: Internal Public Security Missions of Brazil's Military', International Peacekeeping, 26: 2 (2019), pp. 137-64.
} 
first private military company, Áquila Internacional) ${ }^{151}$ or Colonel Allessandro Visacro (for whom "high-intensity criminality"' in Brazil would acquire the characteristics of 'what many call "criminal insurgency"'). ${ }^{152}$ These MINUSTAH results also spread globally. For example, Brazil is involved in confronting the crime-terror-insurgency nexus in West Africa. In 2013, when the United Nations Office on Drugs and Organized Crime (UNODC) started worrying whether insurgents and extremists throughout the region [West Africa] would be in a position to facilitate [cocaine] trafficking, thus drawing resources to their cause and increasing the potential for violence, ${ }^{153}$ Brazil started exporting its pacification expertise westwards. Under the umbrella of a UNODC initiative, Brazil became involved in the creation of a training centre in Guinea-Bissau to 'improve security forces capacities to counter narcotics and organized crime', with the long-term goal of transforming the centre into a 'Regional Training Academy for Portuguese-speaking countries in Africa'. ${ }^{154}$

Brazil also participates in the UN's post-9/11 interventionism. MINUSTAH's Force Commander (2007-09) Lieutenant General Carlos Alberto dos Santos Cruz (a GCW veteran who joined the Brazilian Army four years after the coup of 1964) was assigned to take over the command of the United Nations Organization Stabilization Mission in the Democratic Republic of the Congo (MONUSCO) in 2013 in recognition of his achievements in stabilising Haiti by, as he put it, showing 'no tolerance for the kidnappings, harassment and terror carried out by criminal gangs' ${ }^{155}$ Under his leadership, MONUSCO's Force Intervention Brigade was set up, which has been replicating several of the counterinsurgency practices - including drone operations and the use of special forces used for suppressing Haiti's 'criminal insurgency', thereby transforming MONUSCO into the most violent UN mission so far. ${ }^{156}$

Brazil's counter-insurgency efforts abroad have also had more recent domestic repercussions. Within the context of interim President Michel Temer's (2016-18) federal intervention between February and December 2018 - the first since the end of military rule - in Rio de Janeiro, which placed the military in control of public security, several key actors and discourses from Brazil's overseas pacification efforts travelled home. ${ }^{157}$

\footnotetext{
${ }^{151}$ See www.brasil247.com/brasil/general-do-governo-bolsonaro-e-dono-de-empresa-de-mercenarios, last access 15 Jan. 2020.

${ }^{152}$ Roberto Escoto, 'Guerra irregular: A Brigada de Infantaria Paraquedista do Exército Brasileiro na pacificação de favelas do Rio de Janeiro', Military Review, Jan.-Feb. 2016, pp. 3-4, available at https://jornalhoraextra.com.br/entrevista/entrevista-alessandro-visacro/, last access 15 Jan. 2020. For Visacro's military career, including his publications on 'irregular warfare', see http://eblog.eb.mil.br/index.php/menueasyblog/blogger/alessandrovisacro.html, last access 15 Jan. 2020.

${ }^{153}$ UNODC, 'Transnational Organized Crime in West Africa: A Threat Assessment' (Vienna: UNODC, 2013), p. 9.

${ }^{154}$ See www.unodc.org/unodc/en/drug-trafficking/west-and-central-africa.html, last access 15 Jan. 2020.

${ }^{155}$ Quoted in 'Haiti: UN Peacekeepers Launch Large-scale Operation Against Criminal Gangs', UN News Service, 9 Feb. 2007.

${ }^{156}$ Christoph Harig and Kai Michael Kenkel, 'Are Rising Powers Consistent or Ambiguous Foreign Policy Actors? Brazil, Humanitarian Intervention and the "Graduation Dilemma", International Affairs, 93: 3 (2017), pp. 638-9.

${ }^{157}$ Steinke and Müller, 'Geopolitics', p. 76.
} 
The federal intervention, in fact, has frequently been justified with the successful participation of the Brazilian military in stabilising Haiti. By applying the aboveanalysed discursive logic that elevates local crime problems to the level of military conflict, Brazil's current President Jair Messias Bolsonaro (2019-present), shortly after his election in 2018, stated: 'We are at war. Haiti was also at war. [In Haiti] you found an element with a firearm, you shoot, and then you see what happened. You solve the problem. ${ }^{158}$ Likewise, the troops involved in the federal intervention, many of which participated in MINUSTAH, trained the local police forces based on a course that was similar to the training that MINUSTAH troops received prior to their deployment, thereby deepening the counter-insurgency outlook of local security governance by familiarising police officers with the post-9/11 security epistemology that informed EB-20-MC-10.217 and MINUSTAH's anti-gang operations in Port-au-Prince. ${ }^{159}$

\section{Conclusion}

Latin American militaries are usually portrayed as inherently national institutions. The findings of this article challenge this perspective, and instead show that Latin American militaries are deeply embedded in transnational relations. This has been demonstrated through an analysis of the epistemological work of a transnational 'actor-network' involved in reframing the region's security problems in GWOT terms, and by following the circulation of the underlying concepts and derived policies to the region and beyond. In and through the resulting transnational embedding, globally dominant security epistemologies are reaffirmed, brought into circulation, translated, incorporated into Latin American military doctrine - and exported. While the latter development is a more recent phenomenon, the transnational epistemological aspects and geopolitical dynamics that permeate the former have been a constant feature of Latin American military development throughout the twentieth century, if not earlier. Latin American militaries have always had a predominantly inward-looking perspective. Officially, however, they were supposed to counter external enemies. In this context, the alignment of local military doctrine and practice with globally dominant security epistemologies, by recasting internal security problems in light of global threat perceptions, provides for otherwise hard-to-find legitimating narratives as well as locally and externally provided resources to combat domestic foes.

The alleged recent return of the region's militaries, ${ }^{160}$ in this regard, is not a return at all. In many ways, militaries were never gone. They were only marginalised as internal coercion wielders for the relatively short period between the end of the GCW and the GWOT. What was gone, however, was a global epistemological frame of military reference that could tie local security problems to globally envisioned battle spaces, with domestic theatres of operation turning into 'glocal'

\footnotetext{
${ }^{158}$ Quoted in 'General behind deadly Haiti raid takes aim at Brazil's gangs', Reuters, 29 Nov. 2018.

${ }^{159}$ Steinke and Müller, 'Geopolitics', p. 76.

${ }^{160}$ See https://foreignpolicy.com/2018/10/08/the-military-returns-to-brazilian-politics-bolsonaro/; www.gigahamburg.de/en/publication/the-return-of-the-military; www.nytimes.com/2018/08/14/opinion/mattis-latinamericas-military.html, last access 15 Jan 2020.
} 
battle grounds in the militaries' fights against internal security threats with alleged external connections.

Following $9 / 11$ and the related recasting of local crime problems through a GWOT-oriented militarised security epistemology, this globality has been restored. Accordingly, the region's military institutions, particularly in highly violent contexts such as those of Brazil and Colombia, have been able to tap into this reframing, contributing to enhanced domestic influence, international legitimacy, growing budgets and external deployments. This highlights the resilience of Latin American militaries, including their capacity to update their long-standing 'professionalism of internal warfare' as well as the resulting ability of 'military role expansion'161 according to the strategic embrace of globally dominant threat perceptions, underlying epistemologies and concepts. Recognising this calls for a new research agenda on the region's militaries beyond formal-institutionalist approaches of civil-military relations or simplifying understandings of 'militarisation', which often, due to their built-in methodological nationalism and lack of deeper engagements with the transnational epistemological bases of military vision and practice, are unable to capture these dynamics.

Acknowledgements. I would like to thank Louise Wiuff Moe, the three JLAS reviewers, and the journal's editors for their very helpful comments on earlier versions of this article. I am also grateful for the feedback I received at the workshop 'Reconfiguraciones del gobierno de la seguridad en América Latina: Institucionalización nacional de políticas y procesos y actores internacionales', Universidad Nacional de Córdoba, 23-26 April 2019, in particular from Andrés Antillano, Marcelo Bergman, Paul Hathazy and Gabriel Kessler.

\section{Spanish abstract}

Este artículo ofrece un análisis de los procesos de construcción discursiva transnacional que permearon a la gobernanza de seguridad latinoamericana en las postrimerías del 9/11. Demuestra que la Guerra Global contra el Terror fue una oportunidad para los productores externos de seguridad y los productores locales alineados con éstos en las Américas para redefinir los problemas latinoamericanos de seguridad a través de la promoción de una epistemología de seguridad militarizada, y sus políticas derivadas, que se centró en las 'amenazas convergentes' de la región. Al rastrear las repercusiones discursivas de este replanteamiento epistémico, el artículo muestra que al aprovechar tales discursos, las burocracias militares a lo largo del continente pudieron superar su previa marginación institucional vis-à-vis las agencias civiles. Tal desarrollo contribuyó al renacimiento de los discursos y políticas de contra-insurgencia y contra-terrorismo en la región, permitiendo a países como Colombia y Brasil reposicionarse globalmente al exportar su conocimiento militar para confrontar las amenazas post 9/11 más allá de la región.

Spanish keywords: Guerra Global contra o Terror; comunidades epistêmicas; contra-insurgência; contraterrorismo; Colômbia; Brasil

\footnotetext{
${ }^{161}$ Alfred C. Stepan, 'The New Professionalism of Internal Warfare and Military Role Expansion', in Alfred C. Stepan (ed.), Authoritarian Brazil: Origins, Policies and Futures (New Haven, CN: Yale University Press, 1973), pp. 47-68.
} 


\section{Portuguese abstract}

Este artigo oferece uma análise dos processos de construção discursivos transnacionais que informaram a governança de segurança da América Latina após os atentados de 11 de Setembro. O artigo demonstra que a Guerra Global contra o Terror providenciou uma oportunidade de alinhamento entre inteligências internacionais e locais nas seguranças internas em grande parte das Américas. Isso se deu com o intuito de re-enquadrar os problemas de segurança da América Latina através da promoção de epistemologia de segurança militarizada e suas políticas derivadas, centrada nas 'ameaças convergentes' da região. Ao traçar as repercussões discursivas desse re-enquadramento epistêmico, este artigo mostra que ao acessar estes discursos, burocracias militares em todas as Américas foram capazes de superar sua marginalização institucional anterior em comparação às agências civis. Este desenvolvimento contribuiu para o renascimento de discursos e política de contra-insurgência e contra-terrorismo na região, o que permitiu que países como Brasil e Colômbia se reposicionassem no cenário global através da exportação de seus conhecimentos militares usados para combater ameaças pós 11 de Setembro na região.

Portuguese keywords: Guerra Global contra el Terror; comunidades epistémicas; contra-insurgencia; contra-terrorismo; Colombia; Brasil

Cite this article: Müller M-M (2020). Enter 9/11: Latin America and the Global War on Terror. Journal of Latin American Studies 52, 545-573. https://doi.org/10.1017/S0022216X20000565 